\title{
Egg shell and yolk quality characteristics of layers fed with sugarcane press residue in soya and fish based diets
}

\author{
N. Suma ${ }^{1}$, B. S. Venkatarami Reddy², R. G. Gloridoss ${ }^{2}$, T. M. Prabhu' ${ }^{2}$, C. Basavanta Kumar ${ }^{2}$, B. N. Suresh ${ }^{3}$ and \\ V. T. Shilpa ${ }^{4}$
}

1. Department of Animal Nutrition, Veterinary College, Karnataka Veterinary, Animal and Fisheries Sciences University, Hassan, Karnataka, India; 2. Department of Animal Nutrition, Veterinary College, Karnataka Veterinary, Animal and Fisheries Sciences University, Bengalure, India; 3. Department of Instructional Livestock Farm Complex, Veterinary College, Karnataka Veterinary, Animal and Fisheries Sciences University, Hassan, Karnataka, India; 4. Department of Veterinary Pathology, Veterinary College, Karnataka Veterinary, Animal and Fisheries Sciences University, Hassan, Karnataka, India.

Corresponding author: N. Suma, email: sumavet@gmail.com, BSVR: mansricha@gmail.com, RGG: gideongloridoss@gmail.com,TMP: prabhutmann@gmail.com, CBK: basavantac216@gmail.com, BNS: suresh658@rediffmail.com, VTS: drshilpavt@gmail.com

Received: 23-10-2014, Revised: 12-01-2015, Accepted: 17-01-2015, Published: 25-02-2015

doi: 10.14202/vetworld.2015.232-238. How to cite this article: Suma N, Reddy BSV, Gloridoss RG, Prabhu TM, Kumar CB, Suresh BN, Shilpa VT (2015) Egg shell and yolk quality characteristics of layers fed with sugarcane press residue in soya and fish based diets, Veterinary World, 8(2):232-238.

\begin{abstract}
Aim: Sugarcane press residue (SPR), a by-product of sugarcane industry, which is rich in inorganic salts was assessed at different levels in both soya based and fish based diets of layers for egg shell and yolk quality characteristics.

Materials and Methods: SPR was incorporated in 32-week-old white leghorn layer diets at $0 \%, 5 \%, 10 \%$ and $15 \%$ either in the soya based or fish based diets to form $\mathrm{T}_{1}$ to $\mathrm{T}_{8}$ diets, respectively. Each diet was offered to five replicates of four laying hens each constituting a total of one sixty birds kept for 84 days under colony cages.

Results: Mean egg shell thickness obtained from eggs of experimental hens measured was $0.342,0.329,0.320,0.322$, $0.319,0.332,0.328$ and $0.336 \mathrm{~mm}$ in $\mathrm{T}_{1}$ through $\mathrm{T}_{8}$ groups, respectively. About the main factor effects, both showed nonsignificant results. Similarly, influence of different treatment diets, in imparting colour to the yolks, was found to be nonsignificant $(\mathrm{p}>0.05)$ at different 28-day time intervals. Further, the average yolk index values ranged non-significantly from $0.360\left(\mathrm{~T}_{6}\right)$ to $0.383\left(\mathrm{~T}_{4}\right)$.
\end{abstract}

Conclusion: The SPR can be incorporated into layer diet as a source of inorganic as well as organic nutrients without affecting its egg quality characteristics.

Keywords: egg shell thickness, layer, sugarcane press residue, yolk color, yolk index.

\section{Introduction}

Nearly $3 \%$ of the crushed sugarcane from sugar industries turns into sugarcane press residue (SPR), which is a valuable source of minerals, as well as organic matter. Layer farming is a well organized sector requiring about $6 \mathrm{~m}$ MT of feed annually. As a result, such huge quantity of feed requires the conventional mineral mixture to an extent of $0.18 \mathrm{~m} \mathrm{MT}$ (i.e. about $3 \%$ of feed). Even if $10 \%$ of such required mineral mixture is spared by SPR, there would be an annual utilization of 20,000 tons of dried SPR. Recent reports of SPR as an animal feed indicated that, it can be a potential alternative source of inorganic as well as for organic nutrients for livestock and poultry [1-8].

Hence, a study in layers with inclusion of higher levels of SPR was being taken up to assess the egg quality characteristics.

Copyright: The authors. This article is an open access article licensed under the terms of the Creative Commons Attributin License (http:// creative commons.org/licenses/by/2.0) which permits unrestricted use, distribution and reproduction in any medium, provided the work is properly cited.

\section{Materials and Methods}

Ethical approval

This research work was carried out as per the guidelines in force at the time of carrying out the group experiment as well as in accordance with the Institutional Ethics Committee, Veterinary College, Bangalore guidelines to minimize pain or discomfort of the birds. The study was approved by the Institutional Ethics Committee.

\section{Collection of SPR samples}

The SPR for the study was procured from Shivamogga, Karnataka and was dried under sun till it became air dry. The sample was first screened for proximate composition [9] and then for microbiological examination as well as for multimycotoxin estimation. The calcium and phosphorus contents in SPR were analyzed as per the procedure described by [10].

\section{Formulation of experimental diets}

Two BIS specified [11] practical control diets for both soya $\left(\mathrm{T}_{1}\right)$ and fish based $\left(\mathrm{T}_{5}\right)$ test diets were formulated, while the SPR was included at three levels $(5 \%, 10 \%$ and $15 \%)$ in test diets of both soya 
based $\left(\mathrm{T}_{2}-\mathrm{T}_{4}\right)$ and fish based $\left(\mathrm{T}_{6}-\mathrm{T}_{8}\right)$ types to form a total of 6 treatment diets. Further, enough care was exercised to optimize the levels of most of the essential minerals and $\mathrm{Ca}: \mathrm{P}$ ratio among various diets.

\section{Randomization and experimental care}

A total of 160 BV-300 commercial layers of about 32 weeks age and uniform body weight were housed in two twin-bird colony cages each measuring $15^{\prime \prime} \times 15^{\prime \prime} \times 18^{\prime \prime}$ size to serve as a replication. All birds were divided randomly into 40 groups of 4 birds each, and each of the 8 diets described earlier were offered to five such replications. A completely randomized design was employed to carry out the experiment. The experiment lasted for 84 days, which was conveniently divided into three 28-day interval periods.

\section{Egg characteristics}

All eggs produced in different replicate groups were collected on four occasions, i.e. on $1^{\text {st }}$ day, $28^{\text {th }}$ day, $56^{\text {th }}$ day and on $84^{\text {th }}$ day of the experiment. Each egg so collected during every 28 day intervals was broken open, and the entire contents were carefully placed on a glass slab to analyze different egg characteristics.

\section{Egg shell thickness}

After placing the entire contents of an egg on the glass slab, the shell pieces being made devoid of shell membranes at broad end and a narrow end were carefully selected and their thickness was measured using digital calipers.

\section{Yolk color}

The color of yolk from every broken open egg of different groups at all the 28-day intervals was scored by matching (contrast) technique using Roche yolk color fan [12].

\section{Yolk index (YI)}

YI was calculated for all eggs produced in different groups at every 28-day interval. The yolk height was measured using Ames Haugh Unit Spherometer and diameter by Vernier Calipers. The YI was calculated as:

$\mathrm{YI}=\frac{\text { Yolk height in } \mathrm{mm}}{\text { Yolk diameter in } \mathrm{mm}} \times 100$

\section{Statistical analysis}

The experimental data were statistically analyzed by two-way ANOVA to separate the factor and interaction effect using GraphPad Prism program [13]. Wherever factor effect was significant $(p<0.05)$, the Bonferroni post-test was used with $\mathrm{p}<0.05$ to compare such means.

\section{Results and Discussion}

Composition of SPR and experimental diets: The chemical composition of the SPR sample (Table-1) revealed that it comprised of crude protein (CP)-12.67, ether extract (EE)-7.50, crude fiber (CF)-17.50, total ash-24.62, nitrogen free extract (NFE)-37.71 and AIA-9.51\%. The mineral composition of the said sample of SPR was: Calcium-4.52, Phosphorus-1.25, Magnesium-1.28, Potassium-1.81, Sulphur-2.62\%, Iron-2042, Manganese-228.0, Zinc-36.5, Copper-22.6 and cobalt-236.7 ppm.

The SPR appears to be similar to that of cereal grains in terms of CP (12.67\%) and it's CF content $(17.50 \%)$ resembles that of brans (De-Oiled Rice Bran); values similar to that reported by Singh and Solomon [14]. Although its total ash of $24.62 \%$ and AIA of $9.51 \%$ are unique to itself, the highest EE content of SPR (7.50\%) might concurrently carry significant quantity of waxes, a rich content of cane sugar. The mineral profile of SPR of the present study is well within the range as reported by [14]. However, these values are slightly different than the composition reported by $[15,16]$. The variability in composition may be due to quality of the cane crushed, and the process followed for clarification of cane juice in the sugar industry. As expected, from the proximate analysis of layer diets, the contents of crude protein and NFE tended to decline with incremental levels of SPR in such diets. Such a trend was quite opposite for the rest of the nutrients especially for EE and CF.

The SPR samples were also subjected to screening for microbial contamination, which has revealed that they were negative for Escherichia coli, Bacillus and Salmonella species. Further, the sample under study did not carry any mycotoxin with it.

The proximate composition of experimental layer diets compounded on different occasions of the 84-day experimental period is given in Table-2. The

Table-1: Proximate composition and mineral profile of SPR.

\begin{tabular}{lc}
\hline Parameter & Level \\
\hline Proximate composition (\%) & \\
DM & 90.77 \\
CP & 12.67 \\
EE & 7.50 \\
CF & 17.50 \\
Total ash & 24.62 \\
NFE & 37.71 \\
AIA & 9.51 \\
Mineral profile (\%) & \\
Phosphorus & 1.25 \\
Potassium & 1.81 \\
Calcium & 4.52 \\
Magnesium & 1.28 \\
Sulfur & 2.62 \\
Iron (ppm) & 2042 \\
Manganese (ppm) & 228 \\
Zinc (ppm) & 36.5 \\
Copper (ppm) & 22.6 \\
Cobalt (ppm) & 236.7 \\
Other parameters & \\
pH & 6.35 \\
Organic carbon (\%) & 40.87 \\
\hline
\end{tabular}

$\mathrm{DM}=$ Dry matter, $\mathrm{CP}=$ Crude protein, $\mathrm{EE}=\mathrm{Ether}$ extract, $\mathrm{CF}=$ Crude fiber, NFE=Nitrogen free extract, $\mathrm{SPR}=$ Sugarcane press residue 
results revealed that the proximate analysis of layer diets was similar among all the 8 diets.

\section{Egg shell thickness}

Shell thickness is also an important egg quality factor, which is dependent on dietary regimen among many factors. From Table-3, it can be observed that the dietary groups are statistically $(\mathrm{p}<0.05)$ different from each other on $1^{\text {st }}$ day, $56^{\text {th }}$ day and $84^{\text {th }}$ day of the experimental periods. Although values were statistically $(\mathrm{p}>0.05)$ similar on $28^{\text {th }}$ day, no definitive trend was observed in any particular dietary treatment. The results further show that the shell thickness generally tended to increase till midway of the experiment but declined at $56^{\text {th }}$ and $84^{\text {th }}$ days of the experiment.

The average values ranged from $0.326\left(\mathrm{~T}_{5}\right)$ to $0.359\left(\mathrm{~T}_{1}\right)$ on $1^{\text {st }}$ day; from $0.355\left(\mathrm{~T}_{2}\right)$ to $0.381\left(\mathrm{~T}_{6}\right)$ on $28^{\text {th }}$ day; from $0.298\left(\mathrm{~T}_{7}\right)$ to $0.335\left(\mathrm{~T}_{1}\right)$ on $56^{\text {th }}$ day and from $0.261\left(\mathrm{~T}_{3}\right)$ to $0.311\left(\mathrm{~T}_{8}\right) \mathrm{mm}$ on $84^{\text {th }}$ day (Figure-1). The results of the present study occasionally support the results of [16-19]. The mean egg shell thickness values were $0.331,0.331,0.324$ and $0.329 \mathrm{~mm}$ at $0,5,10$ and 15 per cent levels of inclusion of SPR. The mean values were almost identical among the protein sources $(0.328$ and $0.329 \mathrm{~mm})$.

Amongst the main factor effects, the protein source (soya and fish), though inconsistently, did result in significant $(p<0.05)$ differences at all the time intervals except on $1^{\text {st }}$ day. However, SPR levels failed to show any significance during any time interval (Table-4). Although incremental levels of SPR showed inconsistently increased values during initial stages ( $1^{\text {st }}$ day, $28^{\text {th }}$ day), yet a reduced trend in egg shell strength was observed on $56^{\text {th }}$ and $84^{\text {th }}$ days of the experiment. Egg shell thickness is largely affected by calcium assimilation, under the influence of vitamin $\mathrm{D}_{3}$ including minerals namely zinc and manganese [20]. Inclusion of SPR appears to effectively contribute the said nutrients to support optimal shell thickness since they were replaced to the extent that could be contributable from SPR even at 15\% level of inclusion. In fact, the minerals in SPR might exist in the chelated (organic) form as the SPR allows certain microbial fermentation during its procurements and thus allowing better utilization of minerals.

\section{Yolk color}

Egg yolk color is an important quality characteristic from the consumer point of view. The period wise average yolk color scores of eggs of experimental birds fed different diets are presented in Table- 5 and the factor wise values being presented in Table- 6 .

The values ranged from $5.98\left(\mathrm{~T}_{8}\right)$ to $6.88\left(\mathrm{~T}_{4}\right)$ on $1^{\text {st }}$ day; from $6.23\left(\mathrm{~T}_{2}, \mathrm{~T}_{6}\right)$ to $6.87\left(\mathrm{~T}_{5}\right)$ on $28^{\text {th }}$ day; from $7.08\left(\mathrm{~T}_{1}, \mathrm{~T}_{2}\right)$ to $7.26\left(\mathrm{~T}_{7}\right)$ on $56^{\text {th }}$ day and from 6.96 $\left(\mathrm{T}_{3}\right)$ to $7.33\left(\mathrm{~T}_{1}\right)$ on $84^{\text {th }}$ day of the experimental period. The influence of different treatment diets, in imparting color to the yolks, was found to be non-significant $(p>0.05)$ at different 28-day time intervals. The average yolk color scores of eggs measured at different time intervals are graphically presented in Figure-2.

As regards main factors, the yolk color scores (Table-6) were significantly $(\mathrm{p}<0.05)$ affected by the protein source factor and that too only on the $1^{\text {st }}$ day with a highest value was 6.68 (soya based) as against lowest value of 6.22 (fish based). In fact such trend might be due to the chance factor as evident by the fact that during successive 28-day intervals, no significant differences could surface between the protein sources. Also observed was the fact that the SPR based diets did not enhance the yolk color intensity which otherwise would have been possible in view of the fact that the SPR per se appears to be rich in colouring pigments as that with forages.

YI

The average YI values of eggs of experimental birds fed different diets during different periods are

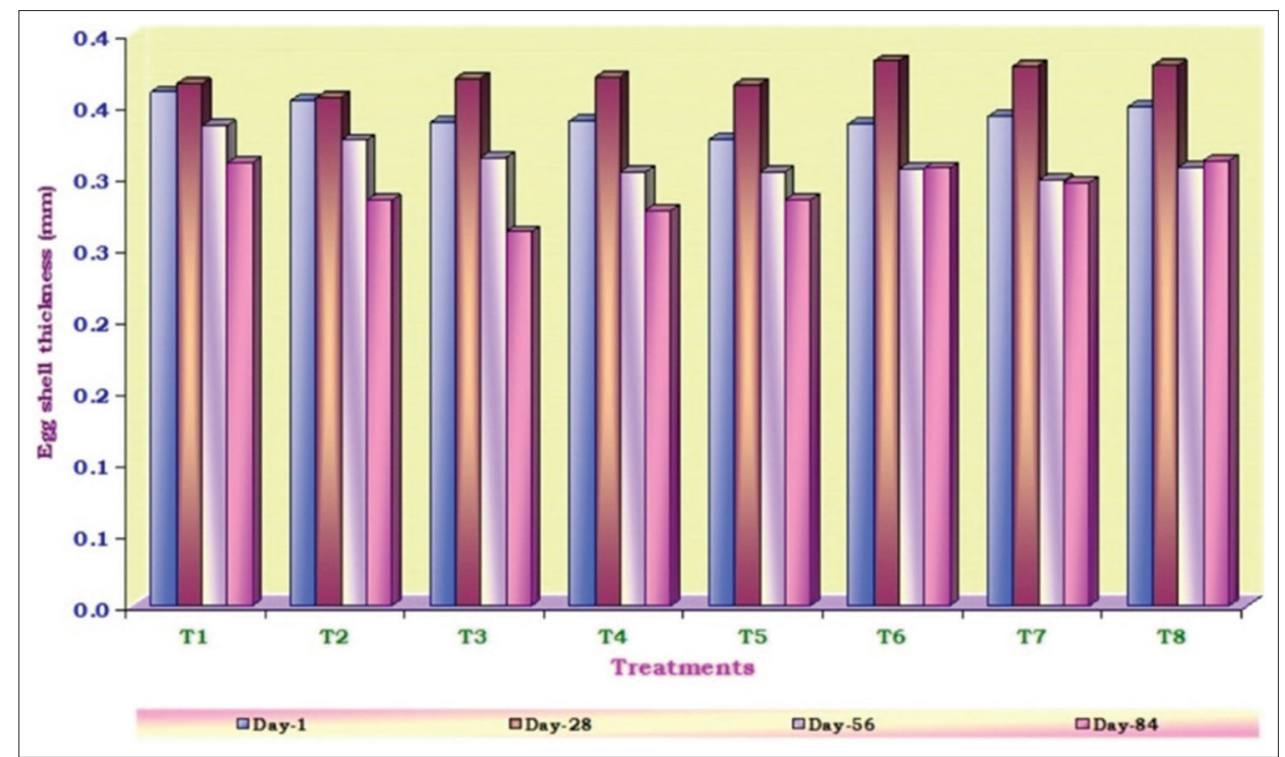

Figure-1: Average shell thickness $(\mathrm{mm})$ of eggs from hens fed different diets at different time intervals. 


\begin{tabular}{|c|c|c|c|c|c|c|c|c|c|c|}
\hline \multicolumn{2}{|c|}{ Dietary description } & \multirow[t]{2}{*}{ Treatments } & \multirow[t]{2}{*}{ DM } & \multirow[t]{2}{*}{ CP } & \multirow[t]{2}{*}{ EE } & \multirow[t]{2}{*}{ CF } & \multirow[t]{2}{*}{ TA } & \multirow[t]{2}{*}{ NFE } & \multirow[t]{2}{*}{$\mathrm{Ca}$} & \multirow[t]{2}{*}{$\mathbf{P}$} \\
\hline Protein source & SPR (\%) & & & & & & & & & \\
\hline \multicolumn{11}{|l|}{ Soya based } \\
\hline Control & 0 & $\mathrm{~T} 1$ & 89.90 & 17.57 & 1.91 & 7.15 & 13.09 & 60.28 & 3.92 & 0.80 \\
\hline \multirow[t]{3}{*}{ Test } & 5 & $\mathrm{~T} 2$ & 89.85 & 17.36 & 2.36 & 7.20 & 13.25 & 59.83 & 3.93 & 0.76 \\
\hline & 10 & T3 & 89.85 & 17.20 & 2.91 & 7.36 & 14.46 & 58.07 & 3.93 & 0.72 \\
\hline & 15 & $\mathrm{~T} 4$ & 89.37 & 17.01 & 3.39 & 7.42 & 14.36 & 57.82 & 3.93 & 0.68 \\
\hline \multicolumn{11}{|l|}{ Fish based } \\
\hline Control & 0 & T5 & 89.56 & 17.48 & 2.26 & 7.19 & 15.17 & 57.91 & 3.92 & 0.81 \\
\hline \multirow[t]{3}{*}{ Test } & 5 & T6 & 89.37 & 17.39 & 2.74 & 7.36 & 15.37 & 57.15 & 3.93 & 0.77 \\
\hline & 10 & T7 & 89.35 & 17.23 & 3.30 & 7.50 & 15.26 & 56.71 & 3.93 & 0.73 \\
\hline & 15 & T8 & 89.26 & 17.09 & 3.83 & 7.60 & 15.81 & 55.67 & 3.93 & 0.69 \\
\hline
\end{tabular}

*Average values of compounded diets on six occasions, $\mathrm{DM}=$ Dry matter, $\mathrm{CP}=$ Crude protein, $\mathrm{EE}=\mathrm{Ether}$ extract, $\mathrm{CF}=\mathrm{Crude}$ fiber, NFE=Nitrogen free extract, $S P R=$ Sugarcane press residue

Table-3: Average shell thickness $(\mathrm{mm})$ of eggs from experimental birds fed different diets during different time intervals.

\begin{tabular}{|c|c|c|c|c|c|c|c|}
\hline \multicolumn{2}{|c|}{ Dietary description } & \multirow[t]{2}{*}{ Treatments } & \multicolumn{5}{|c|}{ Average shell thickness $(\mathrm{mm})$} \\
\hline Protein source & SPR (\%) & & $1^{\text {st }}$ day & $28^{\text {th }}$ day & $56^{\text {th }}$ day & $84^{\text {th }}$ day & Mean \\
\hline \multicolumn{8}{|l|}{ Soya based } \\
\hline Control & 0 & $\mathrm{~T} 1$ & $0.359^{b} \pm 0.008$ & $0.365 \pm 0.007$ & $0.335^{\mathrm{b}} \pm 0.008$ & $0.310^{`} \pm 0.006$ & $0.342 \pm 0.013$ \\
\hline \multirow[t]{3}{*}{ Test } & 5 & $\mathrm{~T} 2$ & $0.353^{b} \pm 0.006$ & $0.355 \pm 0.005$ & $0.326^{\mathrm{ab}} \pm 0.004$ & $0.283^{a b c} \pm 0.007$ & $0.329 \pm 0.017$ \\
\hline & 10 & T3 & $0.338^{\mathrm{ab}} \pm 0.006$ & $0.369 \pm 0.007$ & $0.313^{\mathrm{ab}} \pm 0.008$ & $0.261^{\mathrm{a}} \pm 0.010$ & $0.320 \pm 0.023$ \\
\hline & 15 & $\mathrm{~T} 4$ & $0.339^{\mathrm{ab}} \pm 0.005$ & $0.370 \pm 0.015$ & $0.303^{\mathrm{a}} \pm 0.009$ & $0.276^{\mathrm{ab}} \pm 0.006$ & $0.322 \pm 0.020$ \\
\hline \multicolumn{8}{|l|}{ Fish based } \\
\hline Control & 0 & T5 & $0.326^{\mathrm{a}} \pm 0.002$ & $0.364 \pm 0.012$ & $0.303^{\mathrm{a}} \pm 0.005$ & $0.284^{\mathrm{abc}} \pm 0.004$ & $0.319 \pm 0.017$ \\
\hline \multirow[t]{3}{*}{ Test } & 5 & T6 & $0.337^{\mathrm{ab}} \pm 0.006$ & $0.381 \pm 0.006$ & $0.305^{\mathrm{a}} \pm 0.005$ & $0.306^{`} \pm 0.005$ & $0.332 \pm 0.018$ \\
\hline & 10 & T7 & $0.342^{\mathrm{ab}} \pm 0.006$ & $0.378 \pm 0.009$ & $0.298^{\mathrm{a}} \pm 0.007$ & $0.296^{\mathrm{bc}} \pm 0.007$ & $0.328 \pm 0.020$ \\
\hline & 15 & T8 & $0.349^{\mathrm{ab}} \pm 0.007$ & $0.378 \pm 0.007$ & $0.306^{\mathrm{ab}} \pm 0.005$ & $0.311^{c} \pm 0.005$ & $0.336 \pm 0.017$ \\
\hline $\mathrm{p}$ value & & & 0.002 & 0.548 & 0.077 & 0.001 & 0.241 \\
\hline
\end{tabular}

a-cWithin a column, means bearing at least one common superscript are statistically similar $(p>0.05)$, SPR=Sugarcane press residue

Table-4: Average shell thickness $(\mathrm{mm})$ of eggs as affected by main factors at different time intervals.

\begin{tabular}{|c|c|c|c|c|c|}
\hline & \multicolumn{5}{|c|}{ Average shell thickness (mm) } \\
\hline & $1^{\text {st }}$ day & $28^{\text {th }}$ day & $56^{\text {th }}$ day & $84^{\text {th }}$ day & Mean \\
\hline \multicolumn{6}{|c|}{ i) SPR as main factor } \\
\hline 0 & $0.342 \pm 0.007$ & $0.365 \pm 0.007$ & $0.319 \pm 0.007$ & $0.297 \pm 0.005$ & $0.331 \pm 0.015$ \\
\hline 5 & $0.345 \pm 0.005$ & $0.368 \pm 0.006$ & $0.316 \pm 0.004$ & $0.295 \pm 0.006$ & $0.331 \pm 0.016$ \\
\hline 10 & $0.340 \pm 0.004$ & $0.373 \pm 0.005$ & $0.305 \pm 0.006$ & $0.279 \pm 0.008$ & $0.324 \pm 0.021$ \\
\hline 15 & $0.344 \pm 0.004$ & $0.374 \pm 0.008$ & $0.305 \pm 0.005$ & $0.294 \pm 0.007$ & $0.329 \pm 0.018$ \\
\hline $\mathrm{p}$ value & 0.834 & 0.716 & 0.073 & 0.053 & 0.482 \\
\hline \multicolumn{6}{|c|}{$\begin{array}{l}\text { ii) Protein source as main factor } \\
\text { Protein source }\end{array}$} \\
\hline Soya & $0.343 \pm 0.003$ & $0.365^{\mathrm{a}} \pm 0.002$ & $0.316^{b} \pm 0.001$ & $0.283^{\mathrm{a}} \pm 0.002$ & $0.328 \pm 0.017$ \\
\hline Fish & $0.342 \pm 0.002$ & $0.379^{\mathrm{b}} \pm 0.004$ & $0.303^{a} \pm 0.003$ & $0.304^{b} \pm 0.002$ & $0.329 \pm 0.018$ \\
\hline $\mathrm{p}$ value & 0.340 & 0.011 & 0.001 & 0.001 & 0.890 \\
\hline
\end{tabular}

a-bFor a particular main factor, means common superscripts are statistically similar ( $>0.05)$, SPR=Sugarcane press residue

presented in Table-7 and the main factor wise data are represented in Table-8. From Table-7, it was evident that on $1^{\text {st }}$ day, non-significantly $(\mathrm{p}>0.05)$ lower value of 0.346 was noticed in $\mathrm{T}_{6}$ as against the highest value of 0.385 observed with $T_{1}$. Contrarily, $28^{\text {th }}$ and $56^{\text {th }}$ day values turned out to be significant $(\mathrm{p}<0.01)$ among different treatments. Inclusion of $10 \%, 5 \%$ SPR in fish based diets $\left(\mathrm{T}_{7}, \mathrm{~T}_{6}\right)$ showed significantly lowest values of $0.355,0.368$ as against the highest values of $0.390,0.401$ in $15 \%$ SPR included soya based diets $\left(\mathrm{T}_{4}\right)$ during $28^{\text {th }}, 56^{\text {th }}$ day, respectively. This pattern of significance did not however, persist during the terminal stage $\left(84^{\text {th }}\right.$ day).

The effect observed when the data was analyzed on the basis of main factors was non-significant $(p>0.05)$ as regards the SPR factor was concerned, while the protein source factor revealed significant $(\mathrm{p}<0.05)$ differences only on $28^{\text {th }}$ and $56^{\text {th }}$ days of experiment. Inclusion of SPR at $15 \%$ showed higher values and also that the soya diets were better than 


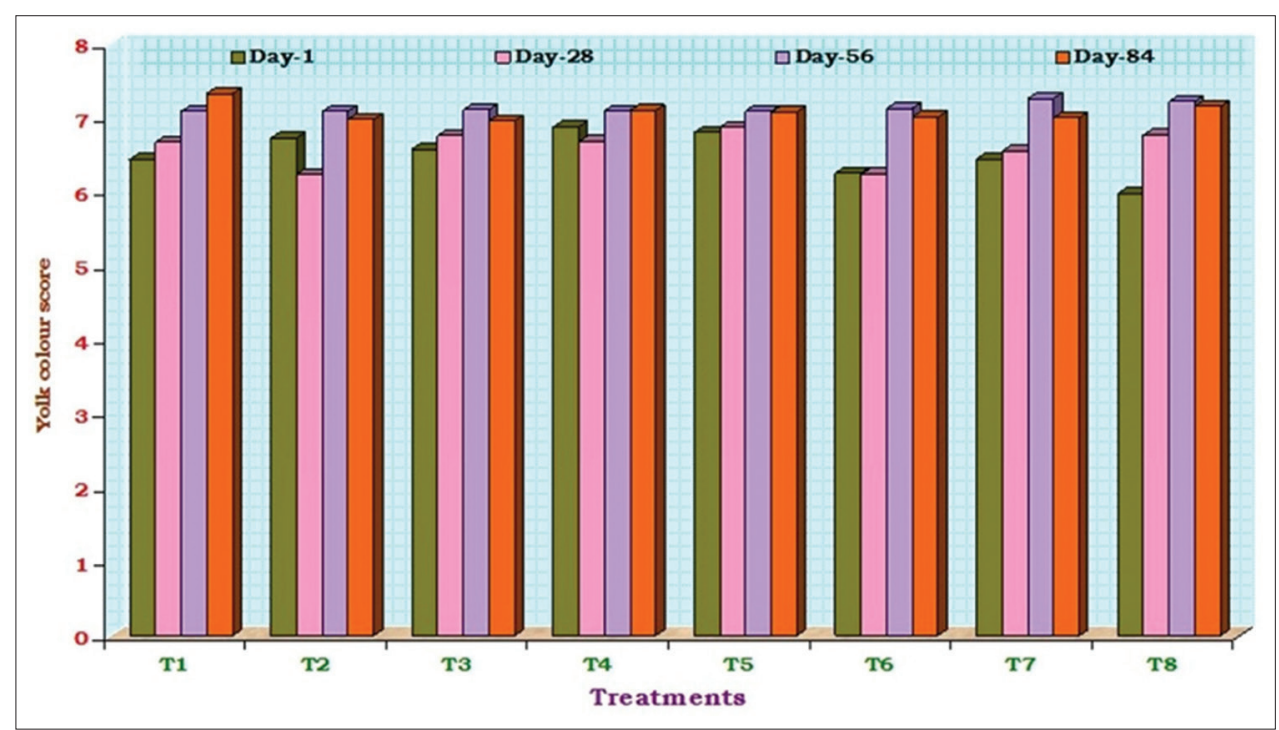

Figure-2: Average yolk colour scores of eggs from experimental birds fed different diets during different time intervals.

Table-5: Average yolk colour scores of eggs from experimental birds fed different diets at different time intervals.

\begin{tabular}{|c|c|c|c|c|c|c|c|}
\hline \multicolumn{2}{|c|}{ Dietary description } & \multirow[t]{2}{*}{ Treatments } & \multicolumn{5}{|c|}{ Average yolk colour score } \\
\hline Protein source & SPR (\%) & & $1^{\text {st }}$ day & $28^{\text {th }}$ day & $56^{\text {th }}$ day & $84^{\text {th }}$ day & Mean \\
\hline \multicolumn{8}{|l|}{ Soya based } \\
\hline Control & 0 & $\mathrm{~T} 1$ & $6.43 \pm 0.30$ & $6.67 \pm 0.18$ & $7.08 \pm 0.28$ & $7.33 \pm 0.15$ & $6.88 \pm 0.20$ \\
\hline \multirow[t]{3}{*}{ Test } & 5 & $\mathrm{~T} 2$ & $6.73 \pm 0.25$ & $6.23 \pm 0.18$ & $7.08 \pm 0.20$ & $6.98 \pm 0.13$ & $6.75 \pm 0.19$ \\
\hline & 10 & T3 & $6.58 \pm 0.16$ & $6.76 \pm 0.08$ & $7.11 \pm 0.12$ & $6.96 \pm 0.13$ & $6.85 \pm 0.12$ \\
\hline & 15 & $\mathrm{~T} 4$ & $6.88 \pm 0.19$ & $6.68 \pm 0.16$ & $7.09 \pm 0.18$ & $7.10 \pm 0.07$ & $6.94 \pm 0.10$ \\
\hline \multicolumn{8}{|l|}{ Fish based } \\
\hline Control & 0 & T5 & $6.80 \pm 0.05$ & $6.87 \pm 0.16$ & $7.09 \pm 0.12$ & $7.06 \pm 0.06$ & $6.96 \pm 0.07$ \\
\hline \multirow[t]{3}{*}{ Test } & 5 & T6 & $6.25 \pm 0.19$ & $6.23 \pm 0.32$ & $7.13 \pm 0.05$ & $7.01 \pm 0.06$ & $6.65 \pm 0.24$ \\
\hline & 10 & T7 & $6.44 \pm 0.21$ & $6.55 \pm 0.21$ & $7.26 \pm 0.15$ & $7.00 \pm 0.06$ & $6.81 \pm 0.19$ \\
\hline & 15 & T8 & $5.98 \pm 0.21$ & $6.77 \pm 0.19$ & $7.22 \pm 0.13$ & $7.15 \pm 0.11$ & $6.78 \pm 0.29$ \\
\hline $\mathrm{p}$ value & & & 0.344 & 0.745 & 0.971 & 0.421 & 0.752 \\
\hline
\end{tabular}

SPR=Sugarcane press residue

Table-6: Average yolk colour scores of eggs as affected by main factors at different time intervals.

\begin{tabular}{|c|c|c|c|c|c|}
\hline & \multicolumn{5}{|c|}{ Average yolk colour score } \\
\hline & $1^{\text {st }}$ day & $28^{\text {th }}$ day & $56^{\text {th }}$ day & $84^{\text {th }}$ day & Mean \\
\hline \multicolumn{6}{|c|}{ i) SPR as main factor } \\
\hline 0 & $6.62 \pm 0.16$ & $6.77 \pm 0.12$ & $7.09 \pm 0.15$ & $7.20 \pm 0.09$ & $6.92 \pm 0.14$ \\
\hline 5 & $6.49 \pm 0.17$ & $6.23 \pm 0.18$ & $7.10 \pm 0.10$ & $6.99 \pm 0.07$ & $6.70 \pm 0.21$ \\
\hline 10 & $6.51 \pm 0.13$ & $6.65 \pm 0.12$ & $7.18 \pm 0.10$ & $6.98 \pm 0.07$ & $6.83 \pm 0.15$ \\
\hline 15 & $6.43 \pm 0.21$ & $6.72 \pm 0.12$ & $7.15 \pm 0.12$ & $7.13 \pm 0.07$ & $6.86 \pm 0.17$ \\
\hline $\mathrm{p}$ value & 0.833 & 0.081 & 0.938 & 0.124 & 0.312 \\
\hline \multicolumn{6}{|c|}{ ii) Protein source as main factor } \\
\hline \multicolumn{6}{|c|}{ Protein source } \\
\hline Soya & $6.68^{\mathrm{b}} \pm 0.13$ & $6.64 \pm 0.09$ & $7.09 \pm 0.06$ & $7.09 \pm 0.08$ & $6.85 \pm 0.14$ \\
\hline Fish & $6.22^{\mathrm{a}} \pm 0.10$ & $6.52 \pm 0.18$ & $7.20 \pm 0.08$ & $7.05 \pm 0.06$ & $6.80 \pm 0.19$ \\
\hline $\mathrm{p}$ value & 0.046 & 0.967 & 0.503 & 0.677 & 0.512 \\
\hline
\end{tabular}

${ }^{\mathrm{a}-\mathrm{b}}$ For a particular main factor, means common superscripts are statistically similar $(p>0.05)$, SPR=Sugarcane press residue

fish diets. Stability of yolk, as reflected by higher YI scores, is important from the point of shelf life of eggs as well as the hatchability. Since SPR contains large amount of lipid portion as wax [16], it might cause mottling of yolks and affect YI, which however did not occur in the present study even at $15 \%$ inclusion of SPR. Thus, egg quality is sustainable with SPR even up to $15 \%$ in layer diets.

\section{Conclusion}

Egg shell and yolk quality characteristics under the study were not affected by the SPR inclusion in layers. Hence, it can be concluded that, SPR can be incorporated as a non-conventional mineral supplement in layer diet for economic poultry production. 
Table-7: Average YI values of eggs from experimental birds fed different diets during different time intervals.

\begin{tabular}{|c|c|c|c|c|c|c|c|}
\hline \multicolumn{2}{|c|}{ Dietary description } & \multirow[t]{2}{*}{ Treatments } & \multicolumn{5}{|c|}{ Average YI } \\
\hline Protein source & SPR (\%) & & $1^{\text {st }}$ day & $28^{\text {th }}$ day & $56^{\text {th }}$ day & $84^{\text {th }}$ day & Mean \\
\hline \multicolumn{8}{|l|}{ Soya based } \\
\hline Control & 0 & $\mathrm{~T} 1$ & $0.385 \pm 0.013$ & $0.374^{\mathrm{abc}} \pm 0.004$ & $0.383^{\mathrm{ab}} \pm 0.007$ & $0.365 \pm 0.003$ & $0.377 \pm 0.005$ \\
\hline \multirow[t]{3}{*}{ Test } & 5 & $\mathrm{~T} 2$ & $0.369 \pm 0.013$ & $0.387^{b c} \pm 0.008$ & $0.389^{\mathrm{ab}} \pm 0.007$ & $0.363 \pm 0.007$ & $0.377 \pm 0.007$ \\
\hline & 10 & T3 & $0.381 \pm 0.005$ & $0.369^{\mathrm{abc}} \pm 0.007$ & $0.391^{\mathrm{ab}} \pm 0.005$ & $0.367 \pm 0.009$ & $0.377 \pm 0.006$ \\
\hline & 15 & T4 & $0.377 \pm 0.006$ & $0.390^{\wedge} \pm 0.006$ & $0.401^{b} \pm 0.007$ & $0.365 \pm 0.011$ & $0.383 \pm 0.008$ \\
\hline \multicolumn{8}{|c|}{ 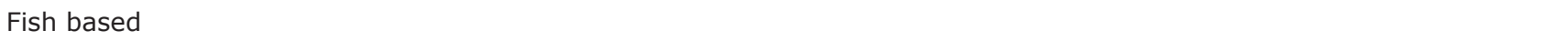 } \\
\hline Control & 0 & T5 & $0.368 \pm 0.004$ & $0.368^{\mathrm{abc}} \pm 0.005$ & $0.386^{\mathrm{ab}} \pm 0.006$ & $0.364 \pm 0.004$ & $0.372 \pm 0.005$ \\
\hline \multirow[t]{3}{*}{ Test } & 5 & T6 & $0.346 \pm 0.017$ & $0.358^{a} \pm 0.008$ & $0.368^{\mathrm{a}} \pm 0.001$ & $0.367 \pm 0.004$ & $0.360 \pm 0.005$ \\
\hline & 10 & T7 & $0.363 \pm 0.006$ & $0.355^{\mathrm{a}} \pm 0.004$ & $0.369^{\mathrm{a}} \pm 0.002$ & $0.361 \pm 0.009$ & $0.362 \pm 0.003$ \\
\hline & 15 & $\mathrm{~T} 8$ & $0.364 \pm 0.003$ & $0.362^{\mathrm{ab}} \pm 0.006$ & $0.379^{\mathrm{ab}} \pm 0.008$ & $0.365 \pm 0.005$ & $0.368 \pm 0.004$ \\
\hline$p$ value & & & 0.975 & 0.009 & 0.001 & 0.918 & 0.436 \\
\hline
\end{tabular}

a-cWithin a column, means bearing at least one common superscript are statistically similar $(p>0.05)$, SPR $=$ Sugarcane press residue, $\mathrm{YI}=$ Yolk index

Table-8: Average YI values of eggs as affected by main factors at different time intervals.

\begin{tabular}{|c|c|c|c|c|c|}
\hline & \multicolumn{5}{|c|}{ Average YI } \\
\hline & $1^{\text {st }}$ day & $28^{\text {th }}$ day & $56^{\text {th }}$ day & $84^{\text {th }}$ day & Mean \\
\hline \multicolumn{6}{|c|}{ i) SPR as main factor } \\
\hline \multicolumn{6}{|c|}{ SPR level (\%) } \\
\hline 0 & $0.377 \pm 0.007$ & $0.371 \pm 0.003$ & $0.384 \pm 0.004$ & $0.365 \pm 0.365$ & $0.374 \pm 0.004$ \\
\hline 5 & $0.357 \pm 0.011$ & $0.372 \pm 0.007$ & $0.379 \pm 0.005$ & $0.365 \pm 0.365$ & $0.368 \pm 0.005$ \\
\hline 10 & $0.372 \pm 0.005$ & $0.362 \pm 0.005$ & $0.380 \pm 0.004$ & $0.364 \pm 0.364$ & $0.370 \pm 0.004$ \\
\hline 15 & $0.371 \pm 0.004$ & $0.376 \pm 0.006$ & $0.390 \pm 0.006$ & $0.365 \pm 0.365$ & $0.375 \pm 0.005$ \\
\hline $\mathrm{p}$ value & 0.249 & 0.149 & 0.209 & 0.999 & 0.248 \\
\hline \multicolumn{6}{|c|}{ ii) Protein source as main factor } \\
\hline $\begin{array}{l}\text { Protein sc } \\
\text { Soya }\end{array}$ & \multicolumn{5}{|c|}{ Protein source } \\
\hline Fish & $0.358 \pm 0.007$ & $0.358^{\mathrm{a}} \pm 0.002$ & $0.372^{\mathrm{a}} \pm 0.003$ & $0.365 \pm 0.003$ & $0.365 \pm 0.004$ \\
\hline $\mathrm{p}$ value & 0.071 & 0.001 & 0.001 & 0.923 & 0.101 \\
\hline
\end{tabular}

${ }^{a-b}$ For a particular main factor, means common superscripts are statistically similar $(p>0.05)$, SPR=Sugarcane press residue, $\mathrm{YI}=$ Yolk index

\section{Authors' Contributions}

NS planned and monitored the work, analyzed the data, drafted the manuscript, BSVR planned, guided and supervised the entire work, reviewed the manuscript. RGG and TMP have given dynamic suggestions during the study. CBK, BNS and VTS have assisted in the work, writing manuscript and reviewed the manuscript. All authors read and approved the final manuscript.

\section{Acknowledgments}

The authors are grateful to the University of Agricultural Sciences, Bangalore for funding the project to carry out the study. Authors thankfully acknowledge the Director, M/s. Good Rich Soya Ltd., Shivamogga, for having arranged the sample of Sugar cane Press Residue from M/s. MPM Sugar Factory, Bhadravati, Shivamogga, to carry out the present study. Authors are also thankful to the Department of Poultry Science, Veterinary College, Bangalore for providing facilities to conduct the trial.

\section{Competing Interests}

The authors have no competing interests.

\section{References}

1. Suma, N., Reddy, B.S.V., Gloridoss, R.G., Rao, N.R., Singh, K.C., Rekha, M.T. and Gomes, A.R. (2007) Egg quality traits of layers influenced by supplementation of different levels of sugarcane press residue. Int. J. Poult. Sci., 6: $102-106$

2. Budeppa, H.B., Reddy, B.S.V., Singh, K.C. and Doss, R.G. (2008) Influence of sugarcane press mud on serum and plasma inorganic phosphorus in broilers. Indian J. Anim. Nutr., 25: 93-96.

3. Suresh, B.N., Reddy, B.S.V., Prabhu, M.M. and Jaishankar, N. (2009a) Carcass characteristics of broilers fed sugarcane press residue with biotechnological agents. Int. J. Poult. Sci., 8: 671-676.

4. Suresh, B.N., Reddy, B.S.V., Prabhu, T.M. and Suma, N. (2009b) Egg quality traits of layers fed sugarcane press residue with biotechnological agents. Int. J. Poult. Sci., 8: 677-683.

5. Suresh, B.N., Reddy, B.S.V., Bolka, P.C., Umashankar, B.C. (2010a) Effect of sugarcane press residue on calcium and phosphorus status of layers. Indian J. Poult. Sci., 45(3): 364-367.

6. Suresh, B.N., Reddy, B.S.V., Jayashankar, N. (2010b) Influence of sugarcane press residue on calcium and phosphorus status of broilers. Indian J. Poult. Sci., 45(3):368-371.

7. Suresh, B.N., Reddy, B.S.V., Prabhu T.M. and Gowda, N.K.S. (2012a) Growth performance of broilers fed sugarcane press residue incorporated diets. Anim. Nutr. Feed Technol., 12: 219-227.

8. Suresh, B.N., Reddy, B.S.V., Gloridoss, R.G. and 
Rajendriran, A.S. (2012b) Production performance of layer chicken fed diets containing sugarcane press residue. Anim. Nutr. Feed Technol., 12: 257-263.

9. Association of Official Analytical Chemists. (1995) Official Methods of Analysis. $15^{\text {th }}$ ed. AOAC, Washington, D.C.

10. Pathak, N.N., Kamra, D.N. and Agarwal, N. (1996) Analytical Techniques in Animal Nutrition Research. International Book Distributing Co., Lucknow.

11. BIS. (1992) Poultry Feed Specifications. $4^{\text {th }}$ Review. Manak Bhavan, Bureau of Indian Standards, New Delhi.

12. Roche Company. (1969) Roche Yolk Colour Fan No. 1155 Printed in Switzerland, DF, Bornstein and Bartov.

13. GraphPad Prism Version 5.01 for Windows, GraphPad Software, San Diego California USA. Available from: http://www.graphpad.com.

14. Singh, B.G. and Solomon, S. (1995) Sugarcane AgroIndustrial Alternatives. Vijay Pimlani for Oxford and IBH
Pub. Co. Pvt. Ltd., New Delhi.

15. Suresh, B.N., Reddy, B.S.V., Prabhu, T.M., Gloridoss, R.G. and Jagadish, B. (2006) Nutritional evaluation of sugarcane pressmud in lambs. Indian J. Anim. Nutr., 23: 47-49.

16. Suresh, B.N. and Reddy, B.S.V. (2011) Dried sugarcane press residue as a potential feed ingredient source of nutrients for poultry. Asian Aust. J. Anim. Sci., 24: 1565-1600.

17. Britton, W.M. (1979) In: Proceeding Georgia Nutrition Conference for the Feed Industry. p63-66.

18. Al-Batshan, H.A., Scheideler, E., Black, B., Grlich, J. and Anderson, K. (1994) Duodenal calcium uptake, femur ash and eggshell quality decline with age and increase following molt. Poult. Sci., 73(10): 1590-1596.

19. Roland, D.A. and Gordon, R. (1997) Phosphorus, calcium optimization requires new approach. Feedstuffs., 69(14): 14-15.

20. Leeson, S. and Summers, J.D. (2001) Nutrition of the Chicken. $4^{\text {th }}$ ed. University Books, NIH6N8 Publications, Canada.

$* * * * * * * *$ 